\title{
GEOCRONOLOGIA DA PROVÍNCIA ALCALINA CENTRAL, PARAGUAI ORIENTAL: CONSIDERAÇÓES PRELIMINARES
}

\author{
V.F.Velázquez ${ }^{1}$ \\ C.B.Gomes ${ }^{2}$ \\ K.Kawashita ${ }^{3}$ \\ P.Comin-Chiaramonti ${ }^{4}$
}

Atualmente, são conhecidos numerosos centros alcalinos na plataforma SulAmericana. Grande parte dessas intrusões encontra-se alinhada preferencialmente junto à borda oriental da Bacia do Paraná, em território brasileiro ou mesmo uruguaio. Por outro lado, pouco ainda se sabe a respeito das manifestações associadas à margem ocidental, com as informações disponiveis confirmando, no entanto, a existência de numerosas ocorrências no território paraguaio e mesmo boliviano.

Embora o número de investigações sobre as rochas alcalinas do Paraguai tenha crescido nos últimos anos, o nivel geral dos conhecimentos, excluídas algumas poucas ocorrências, e ainda insatisfatório. Data de 1987 o primeiro estudo compilativo sobre os corpos (32) até então conhecidos. Valendo-se de evidências notadamente estruturais, LIVIERES \& QUADE (1987) propuseram o seu agrupamento em três grandes províncias: Alto Paraguai, Amambai e Central.

O presente trabalho focaliza as ocorrências dessa última província, que, entre outros aspectos, desperta enorme interesse face ao fato de reunir rochas formadas em duas épocas distintas, Mesozóica e Terciária.

O magmatismo alcalino mesozóico da porção centro-oriental do Paraguai, a ser $r$

\footnotetext{
1Pós-graduação, Departamento de Mineralogia e Petrologia, Instituto de Geociências, USP.

2Departamento de Mineralogia e Petrologia, Instituto de Geociências, USP.

3 Departamento de Geologia Geral, Instituto de Geociências, USP.

${ }^{4}$ Instituto de Mineralogia, Petrografia e Geoquímica, Universidade de Palermo, Itália.
} 
tratado aqui, ocorre associado tectonicamente ao "rift" de Assunção. Nessa área, as alcalinas afloram na forma de "stocks", "plugs", derrames de lava, complexos anelares e enxames de diques. Em geral, elas possuem afinidade potássica e são encontradas na parte central da região cortando discordantemente arenitos silurianos da Formação Caacupé. Contudo, nas suas porções oriental e ocidental, essas rochas acham-se encaixadas em arenitos mesozóicos da Formação Misiones.

Determinações de idade radiométrica (K/Ar) demonstram que a atividade alcalina de natureza potássica se deu, principalmente, entre 120 e $130 \mathrm{Ma}$. Este intervalo de tempo guarda concordância com o registrado para algumas rochas alcalinas da borda oriental da Bacia do Paraná, em especial as ocorrências pertencentes ao cronogrupo de $133 \mathrm{Ma}$ (ULBRICH et al., 1990).

Já os dados Rb/Sr constantes dos trabalhos de VELÁZQUEZ et al. (1990b) e VELÁZQUEZ (1992) (isócronas de referência e interna, respectivamente, de 126,5 77,6 Ma e 127,8 $\pm 7,2$ Ma.) mostram-se inteiramente compativeis com o intervalo acima, o mesmo se verificando com os valores obtidos por Bitschene (1987), de 128 8 Ma., para alguns corpos da área de Sapucai-Ybytyruzú.

Por outro lado, as idades de traços de fissão em apatitas indicam valores bem menores (77,9-94,5 Ma.; GREEN et al., 1991), que, muito possivelmente, estejam refletindo a história do resfriamento dos corpos alcalinos da região ou, alternativamente, marcando a época do estabelecimento do equilíbrio tectônico da área, após o reajuste isostático do "rift".

A idade inferida a partir de estudos paleomagnéticos, em torno de $130 \mathrm{Ma}$. (cf. ERNESTO et al., 1990) é concordante com as idades radiométricas $\mathrm{K} / \mathrm{Ar}$ e $\mathrm{Rb} / \mathrm{Sr}$.

Considerando que o magmatismo da Bacia do Paraná apresenta evolução no sentido do Sul para o Norte, acredita-se, de modo geral, que a atividade toleítica da Formação Serra Geral já se encontrava em pleno progresso quando tiveram ínicio as manifestações alcalinas da Província Central.

Adicionalmente, resultados isotópicos preliminares indicam, para as alcalinas

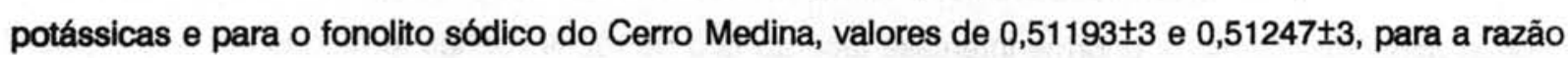
${ }^{143} \mathrm{Nd} /{ }^{144} \mathrm{Nd}$, respectivamente. A notar também que os basaltos tolefiticos da Formação Serra Geral no Paraguai (idade $130 \mathrm{Ma}$.) mostram valores para as razões ${ }^{143} \mathrm{Nd} /{ }^{144} \mathrm{Nd}$ e $\mathrm{R}_{\mathrm{O}}$, respectivamente, de $0,51253 \pm 16$ e 0,70587 9 (MARQUES et al., 1989). Já os nefelinitos terciários da área de Assunção (idade média $45 \mathrm{Ma}$.) exibem valores, respectivamente, de $0,51274 \pm 6$ e $0,70374 \pm 10$ (COMINCHIARAMONTI et al., 1991).

Disso resulta que, para a porção centro-oriental do Paraguai, os dados isotópicos disponiveis são sugestivos da existência de magmas oriundos de fontes enriquecidas em $\mathrm{Sr}$ e $\mathrm{Nd}$ radiogênicos e formados por baixo grau de fusão (3-7\%), a partir um manto peridotito a granada, em 
zonas periféricas relativamente ao ápice da anomalia térmica associada à Bacia do Paraná no Mesozóico. 